\title{
Management of epididymo-orchitis in primary care: results from a large UK primary care database
}

\author{
Amanda Nicholson, Greta Rait, Tarita Murray-Thomas, \\ Gwenda Hughes, Catherine H Mercer and Jackie Cassell
}

\begin{abstract}
Background

Epididymo-orchitis is a common urological presentation in men but recent incidence data are lacking. Guidelines for management recommend detailed investigation and treatment for sexually transmitted pathogens, such as Chlamydia trachomatis. Data from secondary care indicate that these guidelines are poorly followed. It is not known how epididymo-orchitis is managed in UK general practice.
\end{abstract}

Aim

To estimate the incidence of cases of epididymoorchitis seen in UK general practice, and to describe their management.

Design of study

Cohort study.

Setting

UK general practices contributing to the General

Practice Research Database (GPRD).

Method

Men, aged 15-60 years, consulting with a first episode of epididymo-orchitis between 30 June 2003 and 30 June 2008 were identified. All records within 28 days either side of the diagnosis date were analysed to describe the management of these cases (including location) and to compare this management with guidelines.

Results

A total of 12615 patients with a first episode of epididymo-orchitis were identified. The incidence was highest in 2004-2005 (25/10 000) and declined in the later years of the study. Fifty-seven per cent (6943) of patients were managed entirely within general practice. Of these, over $92 \%$ received an antibiotic, with ciprofloxacin being the most common one prescribed. Only $18 \%$ received a prescription for doxycycline. Most men, including those under 35 years, had no investigation recorded and fewer than $3 \%$ had a test for chlamydia.

\section{Conclusion}

These results indicate low rates of specific testing and treatment for sexually transmitted infections in males who attend general practice with symptoms of epididymo-orchitis. There is a need for further research to understand the pattern of care delivered in general practice.

Keywords

chlamydia; electronic health records; epididymitis; incidence; primary health care.

\section{INTRODUCTION}

Acute epididymitis, without or with testicular involvement (here described as epididymo-orchitis), is a common urological condition in men, presenting with unilateral testicular pain and swelling. Recent epidemiological data are lacking, but a previous estimate from UK general practice suggested incidence rates of 40/10 000 person-years, ${ }^{1}$ and outpatient data from the US report epididymo-orchitis as the fifth most common urological diagnosis between the ages of 18 and 50 years. $^{2}$

Existing guidelines are based on a clinical consensus that in men under 35 years, epididymo-orchitis is most commonly caused by a sexually transmitted pathogen such as Chlamydia trachomatis or Neisseria gonorrhoeae..$^{3-7}$ In older men, the infection is more likely to be due to non-sexually transmitted enteric Gram-

A Nicholson, $M S c, P h D, M B B S$, research fellow in primary care epidemiology; J Cassell, FRCP, FFPH, MD, professor of primary care epidemiology, Division of Primary Care and Public Health, Brighton and Sussex Medical School, University of Brighton, Brighton. G Rait, MSc, MD, MRCGP, senior clinical scientist, MRC General Practice Research Framework, London. T Murray-Thomas, MSc, research scientist, General Practice Research Database, The Medicines and Healthcare Products Regulatory Agency, London. G Hughes, BA(Mod), $\mathrm{PhD}$, consultant scientist (epidemiology), Department for Microbiology and Epidemiology of STIs and HIV, Health Protection Agency Centre for Infections, London. CH Mercer, $B S c, M S c, P h D$, senior lecturer, Centre for Sexual Health and HIV Research, Research Department of Infection and Population Health, University College London, London.

Address for correspondence

Amanda Nicholson, Division of Primary Care and Public Health, Brighton and Sussex Medical School, Mayfield House Room 322, University of Brighton, Falmer, Brighton BN1 9PH. E-mail : a.c.nicholson@bsms.ac.uk

Submitted: 17 December 2009; Editor's response: 9 February 2009; final acceptance: 1 March 2010.

(C)British Journal of General Practice

This is the full-length article of an abridged version published in print. Cite this article as: Br J Gen Pract 2010; DOI: 10.3399/bjgp10X532413. 
negative organisms. ${ }^{8}$ The extent of idiopathic or sterile cases is unclear, as some of the literature predates the identification of $C$. trachomatis, but no infection is identified in a sizeable proportion (46\%) of cases. ${ }^{9}$ Novel organisms, such as Mycoplasma genitalium, which are not included in testing regimes, may be involved in such cases. The data underlying this conventional divide at 35 years may, however, be questioned, as they are based on small studies in selected populations. ${ }^{3-7}$ Guidelines from the US and UK suggest a detailed testing schedule, involving $C$. trachomatis, $N$. gonorrhoeae, urethral swabs or firstvoid urine culture, and midstream urinalysis (MSU), followed by antibiotics as indicated by history, with doxycycline for likely $C$. trachomatis infections, ceftriaxone/ciprofloxacin followed by doxycycline for N. gonorrhoeae infections, and ofloxacin/ciprofloxacin for enteric organisms. ${ }^{8,10}$

Effective treatment and management of epididymoorchitis is important for clinical and public health reasons. There are clinical concerns about long-term sequelae including infertility, prostatitis, and strictures. ${ }^{11-14}$ Cases related to sexually transmitted infection (STI) present opportunities to screen for infection and to offer treatment, and for partner notification, which should not be missed. The National Strategy for Sexual Health and HIV has, since 2001, recommended a greater role for primary care providers in the care of STIs. ${ }^{15}$

The sparse literature on the management of epididymo-orchitis raises concerns. A survey of UK urologists indicated low compliance with guidelines, ${ }^{16}$ whereas a survey of genitourinary medicine (GUM) departments reported near-complete adherence. ${ }^{9}$ Data from a US university hospital also suggest low rates of testing for STIs. ${ }^{17}$ Although some cases of epididymoorchitis may present to GUM clinics or direct to an emergency department, most men will attend their GP first. Simms et al reported high attendance rates for epididymo-orchitis in UK primary care. ${ }^{1}$ No studies describing GP management of epididymo-orchitis were identified. There is a need for updated descriptive data using real-time patient records to record the incidence of the disorder and to describe management and hence to inform continuing education.

The current study aimed to estimate the incidence of epididymo-orchitis in primary care between 2003 and 2008. It also aimed to describe the management of patients with this condition, within the practice and beyond, and to assess its adequacy in relation to existing guidelines, including associations between management and various patient and practice factors.

\section{METHOD}

\section{Target population}

The General Practice Research Database (GPRD) is an

\section{How this fits in}

Epididymo-orchitis is a common urological presentation in general practice, which is often related to sexually transmitted infection in younger men. Guidelines for management exist but it is not known how these are followed by GPs. The results of this study, from an anonymised database of primary care electronic records, indicate investigation and treatment that does not address sexually transmitted infection in the majority of men. Further research is required to understand why GPs are not following recommended practice.

electronic database of anonymised longitudinal patient records from general practice..$^{18}$ Established in 1987, it is a UK-wide dataset covering $5.5 \%$ of the population, with data from 460 practices, and is broadly representative of the UK population. There are 3.5 million currently active patients. Records are derived from the GP computer system (VISION) and contain complete prescribing and coded diagnostic and clinical information held in different record tables (Figure 1).

Many laboratory results are now imported directly into the system, and letters received from hospitals will be logged with either full text included or the diagnoses coded. Patient-level data include age and sex and, in 200 of 460 practices (approximately 40\%), a Townsend deprivation index score based on the postcode of the patient. Practice-level data include a deprivation index score based on the postcode of the practice and the $\mathrm{NHS}$ region in which the practice is based.

\section{Study population}

The study period was from 30 June 2003 to 30 June 2008 and the source population was all permanently registered male patients in practices meeting GPRD quality standards. The study population consisted of all men with a first coded diagnosis of epididymo-orchitis within the study period, who were aged 15-60 years at the time of diagnosis. Code lists used for the definition of cases are listed in Appendix 1. Men with a coded diagnosis relating to vasectomy, sterilisation, or instrumentation of the urinary tract 60 days before to 28 days after the date of the epididymo-orchitis code were excluded, as they might have an obvious precipitating cause and hence their management might reasonably not follow guidelines. Men over 60 years were excluded because previous work has found a large proportion of catheter-associated infections in this age group. ${ }^{19}$ Similarly, the vast majority of boys under 15 years will not be sexually active and hence will have low $C$. trachomatis positivity. Appropriate management for these cases could reasonably not follow recommended guidelines and so they were not included in the study.

If multiple diagnostic codes for epididymo-orchitis were recorded for an individual, the date of the first diagnostic code was used as the index date. Analyses 


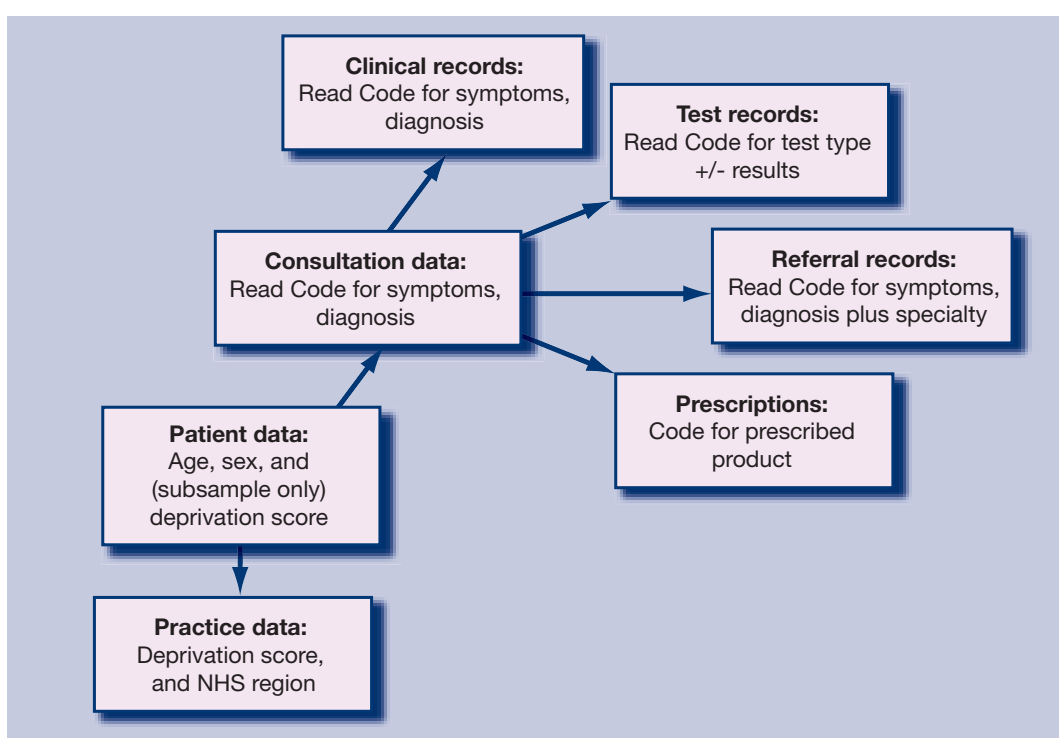

Figure 1. Structure of GPRD database.

were restricted to records in the period 28 days before and after the index date. Cases where the index date was within 28 days of the start or end of the registration at the practice were excluded from descriptions of management.

\section{Description of management}

Testing. A specific chlamydia test was considered to have been carried out if the record contained either a code for a test (for example, 'chlamydia antigen test') or a diagnosis of genital C. trachomatis infection (for example, 'chlamydial epididymitis' or 'chlamydial infection of the lower genitourinary tract'). Codes were identified for tests for $N$. gonorrhoeae. Non-specific microbial tests were considered to have been carried out if there was a code for either appropriate swab (for example, 'urethral swab') or a test such as microscopy, culture and sensitivities with no location given. Codes for bacterial urine testing, including dipstick tests and MSU, were also identified.

Treatment. Variables based on prescription records were created for antibiotic treatments:

- antibiotics recommended for epididymo-orchitis: ofloxacin, doxycycline, ceftriaxone, ciprofloxacin;, ${ }^{810}$ code lists were drawn up using drug substance name, and included all formulations except for inappropriate topical preparations;

- antibiotics suitable for treatment of urinary tract infections (UTIs); code lists included all cephalosporins (British National Formulary (BNF) chapter heading 050102) and amoxicillin, trimethoprim, and nitrofurantoin; and

- all antibiotics: based on BNF heading 0501.

Dosage and duration of use were not assessed.

Location of care. It was considered that a patient had received care for epididymo-orchitis in another healthcare setting if either of the following conditions were met:

- a diagnostic code for the condition or a suggestive symptom code (for example, 'testicular swelling') within the referral record; or

- a code anywhere in the records indicating care elsewhere (for example, 'referral to emergency department', 'seen in GUM clinic'). This category also included less specific terms such as 'discharge summary' or 'letter from specialist'.

If there was no evidence of care elsewhere and there was some evidence of any treatment or testing within the practice, the case was considered to have been managed within the practice only. Men with no evidence of either any management in practice or care elsewhere (that is, where the record had just a diagnostic code) were considered a separate group, due to concerns about completeness of recording, particularly related to care elsewhere. Analyses of management were restricted to males who were managed within the practice only. It did not seem appropriate to assess quality of care if important parts of the care may have been delivered outside the practice and hence not necessarily recorded there.

\section{Statistical analysis}

Data were prepared using Stata (version 10; Statacorp LP, Texas). Calendar years were defined as mid-years from 30 June, so that year 2003 covered 30 June 2003 to 29 June 2004, and so on. Incidence rates were calculated in specific age groups and event years by dividing the number of cases by the appropriate denominator. Age-standardised rates for all ages combined were then obtained by applying these rates to the European standard population. Differences in incidence rates over time and age groups were assessed using Poisson regression. Analyses of management calculated the proportion of patients with various management markers across years and age groups. Logistic regression models investigated factors associated with optimal management.

A series of sensitivity analyses were performed, extending the window for analysis of management from 28 to 42, 60, and 90 days either side of the index date, to assess whether relevant data were being missed by using the 28-day window. Men with diagnostic codes for orchitis only, with no mention of epididymal involvement, were also excluded as appropriate management of viral orchitis would differ.

\section{RESULTS}

\section{Target population and incidence}

Figure 2 summarises the identification and exclusion of 
cases. A total of 12615 males with first diagnosis of epididymo-orchitis were included in incidence analyses; median age was 37 years (interquartile range 28-46 years). Age-standardised incidence of epididymo-orchitis was highest in 2004 (28/10 000 male person-years) and then declined progressively to 21/10 000 male person-years in $2007(P<0.001)$ (Figure $3)$. This decline was greatest in younger age groups $(P$ value for interaction term for age less than 35 years with event year $=0.09$ ). Incidence in males over 45 years was stable during the study period at approximately 20/10 000 person-years.

\section{Management of cases}

Analyses of management included 12270 males, of which 4955 were aged under 35 years (Table 1); $57 \%$ of men (6943) were managed entirely within the practice, and $26 \%$ (3141) had evidence of receiving care elsewhere; $18 \%$ of cases (2186) had no evidence either of management within practice or care elsewhere. Of the 6943 cases managed by primary care (Table 2), $92 \%$ received an antibiotic prescription; $56 \%$ received an antibiotic recommended for epididymo-orchitis, $18 \%$ received doxycycline, and $29 \%$ received an antibiotic indicated for a UTI but not for epididymoorchitis. Recorded investigations were uncommon, with fewer than $3 \%$ of men having a $C$. trachomatis test recorded and only $12 \%$ having had any microbial investigation for urethritis. Testing for $N$. gonorrhoeae was extremely unusual. Urinalysis, including MSU, was the most common form of testing (22\%) but the majority of men had no test or result coded.

There was some evidence that men under 35 years were managed differently from older men, although the differences were small. Younger men were more likely to have no evidence of any management (19.2\% versus $16.8 \%, P<0.001)$ and, correspondingly, were less likely to be managed only within the GP practice

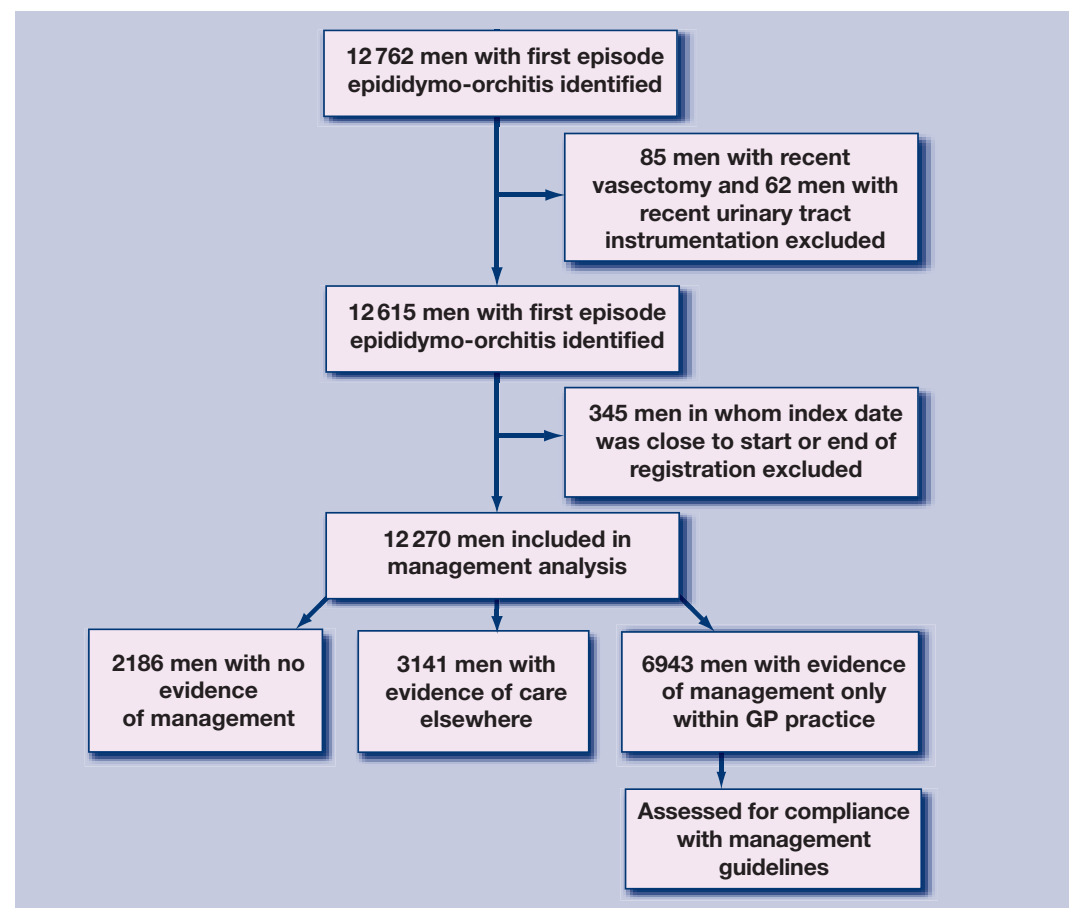

(55.2\% versus $57.7 \%, P=0.003$ ). Of those managed by GPs, younger men were more likely to be prescribed doxycycline and have a $C$. trachomatis or microbial test than older men, and less likely to be treated or investigated for a UTI.

The proportion of patients managed within general practice was stable across the study period but there was a fall in the proportion of cases with no evidence of management in both age bands, and this was matched by an increase in the proportion with evidence of care elsewhere (Table 1). When trends in treatment and investigation over the study period were examined (not shown in tables), the use of ciprofloxacin increased over time, rising from $31 \%$ to $44 \%$ in both age bands $(P<0.001)$, but there was no evidence of an increase in
Figure 2. Flow chart of study: patient identification and exclusions.

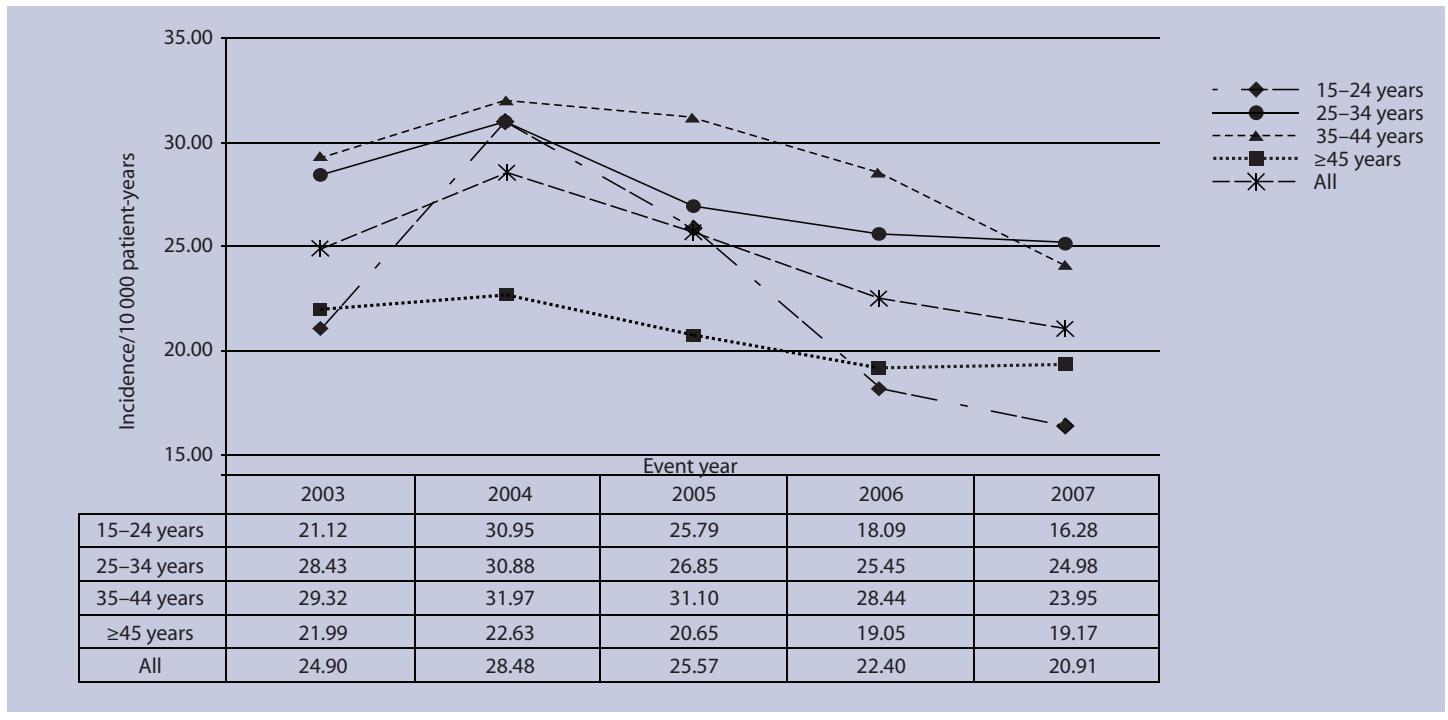

Figure 3. Incidence of first episode of epididymoorchitis in primary care: 2003-2007. 
Table 1. Location of management of epididymo-orchitis cases seen in primary care.

\begin{tabular}{|c|c|c|c|c|c|c|c|c|}
\hline & \multicolumn{4}{|c|}{ Aged <35 years, $n(\%)$} & \multicolumn{4}{|c|}{ Aged $\geq 35$ years, $n(\%)$} \\
\hline & $n$ & $\begin{array}{l}\text { Evidence of } \\
\text { care elsewhere }\end{array}$ & $\begin{array}{c}\text { Managed } \\
\text { only in practice }\end{array}$ & $\begin{array}{c}\text { No evidence } \\
\text { of management }\end{array}$ & $n$ & $\begin{array}{l}\text { Evidence of } \\
\text { care elsewhere }\end{array}$ & $\begin{array}{l}\text { Managed only } \\
\text { in practice }\end{array}$ & $\begin{array}{c}\text { No evidence } \\
\text { of management }\end{array}$ \\
\hline 2003 & 973 & 203 (20.9) & $551(56.6)$ & $219(22.5)$ & 1484 & 291 (19.6) & 889 (59.9) & $304(20.5)$ \\
\hline 2004 & 1232 & $321(26.1)$ & $642(52.1)$ & $269(21.8)$ & 1609 & $356(22.1)$ & $954(59.3)$ & 299 (18.6) \\
\hline 2005 & 1060 & $276(26.0)$ & $584(55.1)$ & $200(18.9)$ & 1533 & $431(28.1)$ & $852(55.6)$ & 250 (16.3) \\
\hline 2006 & 871 & $230(26.4)$ & $495(56.8)$ & $146(16.8)$ & 1416 & $388(27.4)$ & $800(56.5)$ & 228 (16.1) \\
\hline 2007 & 819 & $244(29.8)$ & 454 (55.4) & $121(14.8)$ & 1273 & $401(31.5)$ & $722(56.7)$ & 150 (11.8) \\
\hline \multicolumn{2}{|c|}{$P$-value for trend } & $<0.001$ & 0.60 & $<0.001$ & & $<0.001$ & 0.02 & $<0.001$ \\
\hline Total & 4955 & $1274(25.7)$ & $2726(55.0)$ & 955 (19.3) & 7315 & 1867 (25.5) & 4217 (57.7) & $1231(16.8)$ \\
\hline
\end{tabular}

doxycycline prescriptions or $C$. trachomatis testing in either age group during the study period.

\section{Factors associated with optimal management}

Table 3 summarises patient and practice factors associated with receiving a prescription for doxycycline, the preferred treatment for chlamydia. This multivariate analysis indicates that patients over 35 years were $20 \%$ less likely to receive doxycycline, and confirms no increase in the use of doxycycline over the study period. Practices in the most and least deprived areas were less likely to prescribe doxycycline. Patterns were similar when analyses were restricted to younger men. In the subsample (54\%) for whom an individual deprivation index was available, patients from the least deprived quintile were least likely to receive doxycycline. The odds ratio (adjusted for age group and event year) for the least deprived quintile compared to all others was 0.9 (95\% Cl $=0.7$ to 1.2$)$ for all men $(n=3498)$ and 1.0
$(95 \% \mathrm{Cl}=0.7$ to 0.8$)$ for men aged under 35 years $(n$ $=1350$ ).

Excluding 1575 men with diagnostic codes for orchitis did not alter the results. Sensitivity analyses showed that the proportion of cases with evidence of care elsewhere increased as the time window for management was widened for patients managed within practice, but the pattern of care was similar (Appendix 2).

\section{DISCUSSION}

\section{Summary of main findings}

A substantial caseload of epididymo-orchitis is seen in primary care and the condition is not restricted to younger men. Incidence fell between 2003 and 2008, with the greatest decline in younger age groups and a relatively stable incidence in older men. Fifty-seven per cent of all cases were managed entirely within primary care and of these, $56 \%$ received recommended antibiotics but very few had appropriate testing.

Table 2. Treatment and investigation of cases managed within practice only.

\begin{tabular}{|c|c|c|c|c|}
\hline & & $n(\%$ & & \\
\hline & $\begin{array}{c}\text { All, } \\
n=6943\end{array}$ & $\begin{array}{c}\text { Aged }<35 \text { years }, \\
n=2726\end{array}$ & $\begin{array}{c}\text { Aged } \geq 35 \text { years }, \\
n=4217\end{array}$ & $\begin{array}{l}P \text {-value for difference } \\
\text { between age groups }\end{array}$ \\
\hline Treatment & & & & \\
\hline Antibiotic recommended for $C$ & mydia trachon & & & \\
\hline Doxycycline & $1270(18.3)$ & $541(19.9)$ & 729 (17.3) & 0.007 \\
\hline Ciprofloxacin & 2511 (36.2) & $941(34.5)$ & $1570(37.2)$ & 0.022 \\
\hline Ofloxacin & $224(3.2)$ & $88(3.2)$ & $136(3.2)$ & 0.990 \\
\hline Ceftriaxone & 0 & 0 & 0 & \\
\hline Any one of the above ${ }^{a}$ & $3859(55.6)$ & $1514(55.5)$ & 2345 (55.6) & 0.980 \\
\hline Other UTI antibiotic ${ }^{b}$ & $2045(29.4)$ & $796(28.9)$ & $1249(29.6)$ & 0.720 \\
\hline Any other antibiotic $^{b}$ & 508 (7.3) & $212(7.8)$ & $296(7.0)$ & 0.230 \\
\hline Any antibiotic ${ }^{a}$ & $6412(92.4)$ & $2522(92.5)$ & 3890 (92.3) & 0.640 \\
\hline Investigation & & & & \\
\hline Chlamydia test & $180(2.6)$ & $120(4.4)$ & $60(1.4)$ & $<0.001$ \\
\hline Neisseria gonorrhoeae test & $4(0.06)$ & $3(0.1)$ & $1(0.02)$ & 0.146 \\
\hline Any microbial test & $649(9.4)$ & $284(10.4)$ & $365(8.7)$ & 0.014 \\
\hline Urine test ${ }^{\circ}$ & $1507(21.7)$ & $547(20.1)$ & $960(22.7)$ & 0.008 \\
\hline
\end{tabular}

${ }^{a}$ Total of rows above. ${ }^{~} E x c l u d e s$ all antibiotics in preceding rows of tables. 'Bacterial urine testing, including dipstick tests and midstream urinalysis. UTI = urinary tract infection. 


\section{Strengths and limitations of the study}

This research examined an unselected population of men with epididymo-orchitis seen in primary care. To the authors' knowledge this is the first study that has considered management by GPs rather than GUM clinics or in secondary care. By using real-time patient records, the study avoided the response bias that affects self-report questionnaire data completed by doctors. As electronic patient record databases are designed primarily for patient care, caution is required. Only coded data were used (based on Read Codes) and information entered as free text in the record was not accessed. This means that there may be some errors both in the classification of men as cases and in the assessment of their management. As epididymoorchitis is not included in any Quality and Outcomes Framework targets, there is little incentive for GPs to code all elements of the consultation beyond diagnosis and prescribing accurately. Relevant management information, such as advice to attend a GUM clinic, may be present in text only.

Definition as a case requires the GP both to make a diagnosis and record it as a code. The study may have excluded cases diagnosed by the GP but coded using non-specific symptoms rather than a diagnostic code. Equally, some cases with a diagnostic code may not truly reflect a confirmed diagnosis, although sensitivity analyses suggest that the inclusion of cases of possible viral orchitis has not affected results.

The classification of the location of management was complex. The referral (rather than clinical) record was used in the study as evidence of care elsewhere, but this record file may not be used consistently by GPs. Some Read Codes taken as evidence of care elsewhere were non-specific and may not have been actually related to the epididymo-orchitis diagnosis. As expected, as the management window was widened, the proportion with evidence of care elsewhere increased but more unrelated referrals may have been included. The proportion with evidence of care elsewhere increased during the study period, which may be due to better recording of referrals. It was assumed that a prescription was for epididymoorchitis based on the interval between date of prescription and date of diagnostic code, with similar potential for an overestimate of antibiotic use. However, sensitivity analyses did not indicate that the estimates of treatment were dependent on the length of the management window.

\section{Comparison with existing literature}

Incidence estimates for epididymo-orchitis for 1994-2001, based on the Royal College of General Practitioners Weekly Returns Service, ${ }^{1}$ are higher than those in the present study (38/10 000 person-years in

\begin{tabular}{|c|c|c|}
\hline & \multicolumn{2}{|c|}{$\begin{array}{l}\text { Adjusted odds ratio for receiving doxycycline } \\
(95 \% \mathrm{Cls}) \text { for those managed within practice only }\end{array}$} \\
\hline & All ages $(n=6928)$ & $\leq 35$ years $(n=2476)$ \\
\hline \multicolumn{3}{|l|}{ Age group, years } \\
\hline $15-24$ & $1.0(0.8$ to 1.2$)$ & \\
\hline 24-35 & 1 & \\
\hline $35-44$ & $0.8(0.7$ to 1.0$)$ & \\
\hline $45-60$ & $0.8(0.7$ to 1.0$)$ & \\
\hline \multicolumn{3}{|l|}{ Event year } \\
\hline 2003 & 1 & 1 \\
\hline 2004 & $1.1(0.9$ to 1.3$)$ & $1.1(0.8$ to 1.4$)$ \\
\hline 2005 & $1.1(0.9$ to 1.3$)$ & $1.1(0.8$ to 1.4$)$ \\
\hline 2006 & $1.1(0.9$ to 1.3$)$ & $1.1(0.8$ to 1.5$)$ \\
\hline 2007 & $1.2(1.0$ to 1.4$)$ & $1.1(0.8$ to 1.5$)$ \\
\hline \multicolumn{3}{|c|}{ Practice quintile of deprivation } \\
\hline 1 (least deprived) & 1 & 1 \\
\hline 2 & 1.5 (1.3 to 1.9$)$ & $1.2(0.9$ to 1.7$)$ \\
\hline 3 & $1.4(1.1$ to 1.7$)$ & $1.3(0.9$ to 1.7$)$ \\
\hline 4 & $1.3(1.1$ to 1.6$)$ & $1.4(1.0$ to 1.8$)$ \\
\hline 5 (most deprived) & $1.0(0.8$ to 1.2$)$ & $1.0(0.7$ to 1.3$)$ \\
\hline
\end{tabular}

2001). The difference is probably because this study counted first episode only, whereas the previous estimate counted repeat episodes and relied on the GP classification of new/follow-up consultation.

The decline in incidence may be due to a true fall in incidence of the condition, or may reflect more cases being seen outside general practice, or changes in coding practice. There are consistent data, including from the GPRD, that pelvic inflammatory disease, an associated infection in women, is declining. ${ }^{20-22}$ It is unclear how this is related to increasing rates of testing for chlamydia in England. ${ }^{23}$ Literature reviews of the impact of $C$. trachomatis screening on health outcomes have found little evidence that pelvic inflammatory disease in women is reduced, and the effect on male health outcomes such as epididymoorchitis has not been studied..$^{24,25}$ It is possible that the National Chlamydia Screening Programme in England has contributed to the decline in incidence observed, though it is estimated that coverage rates of $30 \%$ are required to reduce $C$. trachomatis prevalence by $29 \% .{ }^{26}$ The greater decline in younger age groups is consistent with a role for the screening programme.

Given the assumed contribution of STls to epididymo-orchitis, it was surprising to find that incidence was relatively consistent across all age groups of men up to the age of 45 years. This was also reported in a survey of cases in US hospitals, where patients over 35 years accounted for more than $50 \%$ of cases, although this study relied only on the number of cases. ${ }^{27}$ The present data confirm that the disease is not restricted to younger men. It was also surprising to find that there was some evidence that men from more affluent areas were less likely to 
receive doxycycline. This should be explored in other studies.

Ciprofloxacin was the most commonly prescribed antibiotic, which is consistent with reports from secondary care where quinolones were the treatment of choice for epididymo-orchitis, ${ }^{16,17}$ whereas doxycycline treatment was the norm in GUM clinics. ${ }^{9}$ The extremely low rates of $C$. trachomatis testing reported in the present study are consistent with reports of $3 \%$ in a US hospital. ${ }^{17}$ Cassell et al, using data from a British national probability survey, reported that few men received a $C$. trachomatis diagnosis in general practice, ${ }^{28}$ and that rates of non-specific urethritis (often a clinical diagnosis) were disproportionately high in comparison with chlamydia in primary care. ${ }^{19}$ The rates of investigation for urethritis found in the present study are even lower than the $18 \%$ reported by UK urologists. ${ }^{16}$

\section{Implications clinical practice and future research}

The management of epididymo-orchitis in primary care fails to recognise the need to test for a STI, even in younger men. Syndromic treatment is often given with no apparent investigation. This is consistent with what has been seen in urology but is of greater concern due to the large numbers of patients seen in general practice and the potential public health impact. Potential reasons for this syndromic treatment include reluctance of the doctor or patient to undertake invasive and potentially embarrassing tests. There is a need for further research to understand the pattern of care delivered in general practice. Surprisingly high rates of epididymo-orchitis were found in men over 35 years in this study. Work is needed to understand the aetiology, particularly in older men, so that guidelines are evidence based. The accuracy of coded information in primary care databases needs to be confirmed, and the authors plan to consult anonymised free text in a selection of patients to investigate whether textual data alter the estimates of management.

\section{Funding body}

Access to the GPRD database was funded through the Medical Research Council's license agreement with the Medicines and Healthcare products Regulatory Agency.

\section{Ethical approval}

The study was approved by the GPRD Independent Scientific Advisory Committee (protocol number 08_097).

\section{Competing interests}

The authors have stated that there are none.

\section{Acknowledgements}

This study is based in part on data from the Full Feature General Practice Research Database obtained under license from the UK Medicines and Healthcare products Regulatory Agency. However, the interpretation and contained in this study are those of the authors alone.

\section{Discuss this article}

Contribute and read comments about this article on the Discussion Forum: http://www.rcgp.org.uk/bjgp-discuss

\section{REFERENCES}

1. Simms I, Fleming DM, Lowndes CM, et al. Surveillance of sexually transmitted diseases in general practice: a description of trends in the Royal College of General Practitioners Weekly Returns Service between 1994 and 2001. Int J STD AIDS 2006; 17(10): 693-698.

2. Collins MM, Stafford RS, O'Leary MP, Barry MJ. How common is prostatitis? A national survey of physician visits. J Urol 1998; 159(4): 1224-1228.

3. Hoosen AA, O'Farrell N, van den EJ. Microbiology of acute epididymitis in a developing community. Genitourin Med 1993; 69(5): 361-363.

4. De JZ, Pontonnier F, Plante P, et al. The frequency of Chlamydia trachomatis in acute epididymitis. Br J Urol 1988; 62(1): 76-78.

5. Grant JB, Costello CB, Sequeira PJ, Blacklock NJ. The role of Chlamydia trachomatis in epididymitis. Br J Urol 1987; 60(4): 355-359.

6. Mulcahy FM, Bignell CJ, Rajakumar R, et al. Prevalence of chlamydial infection in acute epididymo-orchitis. Genitourin Med 1987; 63(1): $16-18$.

7. Hawkins DA, Taylor-Robinson D, Thomas BJ, Harris JR. Microbiological survey of acute epididymitis. Genitourin Med 1986; 62(5): 342-344.

8. British Association for Sexual Health and HIV. 2001 Guideline for the management of epididymo-orchitis. http://www.bashh.org/documents/31/31.pdf (accessed 9 Mar 2010).

9. Dale AWS, Wilson JD, Forster GE, et al. Management of epididymoorchitis in genitourinary medicine clinics in the United Kingdom's North Thames region 2000. Int J STD AIDS 2001; 12(5):342-345.

10. Centers for Disease Control and Prevention, Department of Health and Human Services. Sexually Transmitted Diseases Treatment Guidelines 2006. Epididymitis.

http://www.cdc.gov/std/Treatment/2006/epididymitis.htm (accessed 9 Mar 2010).

11. Trei JS, Canas LC, Gould PL. Reproductive tract complications associated with Chlamydia trachomatis infection in US Air Force males within 4 years of testing. Sex Transm Dis 2008; 35(9): 827-833.

12. McMillan A, Pakianathan M, Mao JH, Macintyre CC. Urethral stricture and urethritis in men in Scotland. Genitourin Med 1994; 70(6): 403-405.

13. Weidner W, Schiefer HG, Krauss H. Role of Chlamydia trachomatis and mycoplasmas in chronic prostatitis. A review. Urol Int 1988; 43(3): 167-173.

14. Ness RB, Markovic N, Carlson CL, Coughlin MT. Do men become infertile after having sexually transmitted urethritis? An epidemiologic examination. Fertil Steril 1997; 68(2): 205-213.

15. Department of Health. Better prevention, better services, better sexual health - the national strategy for sexual health and HIV. London: Department of Health, 2001.

16. Drury NE, Dyer JP, Breitenfeldt N, et al. Management of acute epididymitis: are European guidelines being followed? Eur Urol 2004; 46(4): 522-524.

17. Tracy CR, Costabile RA. The evaluation and treatment of acute epididymitis in a large university based population: are CDC guidelines being followed? World J Urol 2009; 27(2): 259-263.

18. General Practice Research Database. http://www.gprd.com/home/ (accessed 9 Mar 2010).

19. Cassell JA, Mercer CH, Sutcliffe L, et al. Trends in sexually transmitted infections in general practice 1990-2000: population based study using data from the UK general practice research database. BMJ 2006; 332(7537): 332-334.

20. Owusu-Edusei K, Bohm MK, Chesson HW, Kent CK. Chlamydia and gonorrhoea screening and pelvic inflammatory disease diagnoses: can simple time series analyses provide some insights? Oral presentation at 18 th Conference of International Society for STD Research, London 2009, OS.2.6.06.

21. Rekart M, Gilbert M, Kim P, et al. Documenting the success of Chlamydia control in British Columbia. 2009. Poster presentation at 18th Conference of International Society for STD Research, London 2009. P.4.64.

22. French C, Hughes G, Yung M, et al. Estimation of the rate of pelvic inflammatory disease diagnoses: trends in England, 2000-2008. Sex Transm Dis. In press.

23. NHS National Chlamydia Screening Program. New Frontiers: Annual report of the National National Chlamydia Screening Programme in England 2005/6.

http://www.chlamydiascreening.nhs.uk/ps/assets/pdfs/publications/rep orts/NCSPa-rprt-05_06.pdf (accessed 9 Mar 2010). 
24. Low N, Bender N, Nartey L, et al. Effectiveness of chlamydia screening: systematic review. Int J Epidemiol 2009; 38(2): 435-448.

25. Gift TL, Gaydos CA, Kent CK, et al. The program cost and costeffectiveness of screening men for Chlamydia to prevent pelvic inflammatory disease in women. Sex Transm Dis 2008; 35(11 suppl): S66-S75.

26. Turner KM, Adams EJ, Lamontagne DS, et al. Modelling the effectiveness of chlamydia screening in England. Sex Transm Infect 2006; 82(6): 496-502.

27. Tracy CR, Steers WD, Costabile R. Diagnosis and management of epididymitis. Urol Clin North Am 2008; 35(1): 101-108.

28. Cassell JA, Mercer CH, Fenton KA, et al. A comparison of the population diagnosed with chlamydia in primary care with that diagnosed in sexual health clinics: implications for a national screening programme. Public Health 2006; 120(10): 984-988.

\begin{tabular}{|c|c|c|}
\hline GPRD Medical Code & Read/OXMIS Term & Read/ OXMIS Code \\
\hline 205990 & A981311 & Acute gonococcal orchitis \\
\hline 207436 & K242300 & Epididymo-orchitis in diseases EC \\
\hline 216427 & K241200 & Epididymitis unspecified \\
\hline 216428 & K242000 & Epididymo-orchitis with abscess \\
\hline 220371 & 604 AT & ABSCESS TESTIS/TESTICLE \\
\hline 237903 & 0980F & ORCHITIS GONOCOCCAL* \\
\hline 238377 & $6075 T T$ & INFECTION TESTIS \\
\hline 243662 & K241100 & Epididymitis with no abscess \\
\hline 243664 & K241z00 & Epididymitis NOS \\
\hline 252783 & K241.00 & Epididymitis \\
\hline 252784 & K241000 & Epididymitis with abscess \\
\hline 252785 & K241300 & Epididymitis in diseases EC \\
\hline 252786 & K24z.00 & Orchitis and epididymitis NOS \\
\hline 256799 & $604 \mathrm{BA}$ & ORCHITIS ACUTE ${ }^{\star}$ \\
\hline 266026 & $604 \mathrm{AE}$ & ABSCESS EPIDIDYMIS \\
\hline 266027 & $604 \mathrm{C}$ & ORCHITIS NOT MUMPS \\
\hline 271289 & K242200 & Epididymo-orchitis unspecified \\
\hline 280340 & K241600 & Chlamydial epididymitis \\
\hline 280341 & K242.00 & Epididymo-orchitis \\
\hline 280342 & K242100 & Epididymo-orchitis with no abscess \\
\hline 289462 & K241400 & Acute epididymitis \\
\hline 298729 & K242z00 & Epididymo-orchitis NOS \\
\hline 304349 & $604 \mathrm{~A}$ & EPIDIDYMITIS \\
\hline 304350 & $604 \mathrm{~B}$ & ORCHITIS \\
\hline 304351 & $604 \mathrm{D}$ & EPIDIDYMO-ORCHITIS \\
\hline 207435 & K240z00 & Orchitis NOS \\
\hline 234647 & K240200 & Orchitis unspecified \\
\hline 252780 & K24..00 & Orchitis and epididymitis \\
\hline 252781 & K240000 & Orchitis with abscess \\
\hline 252782 & K240300 & Orchitis in diseases EC \\
\hline 280339 & K240100 & Orchitis with no abscess \\
\hline 298728 & K240.00 & Orchitis \\
\hline 265494 & 0980E & GONOCOCCAL EPIDIDYMITIS \\
\hline 265495 & 0980EF & GONOCOCCAL EPIDIDYMO-ORCHITIS \\
\hline 278873 & A981300 & Acute gonococcal epididymo-orchitis \\
\hline 220376 & $6075 A D$ & ABSCESS VAS DEFERENS \\
\hline
\end{tabular}


Appendix 1. Code lists:

B. Code lists for chlamydia test.

\begin{tabular}{|c|c|c|}
\hline GPRD Medical Code & Read/OXMIS Term & Read/ OXMIS Code \\
\hline 205965 & Chlamydial infection, unspecified & A78AW00 \\
\hline 205969 & Other viral or chlamydial disease NOS & A7z..00 \\
\hline 206063 & [X]Other chlamydial diseases & Ayu6100 \\
\hline 207468 & Female chlamydial pelvic inflammatory disease & K40y100 \\
\hline 214967 & Chlamydial inf of pelviperitoneum oth genitourinary organs & A78A300 \\
\hline 215059 & {$[\mathrm{X}]$ Chlamydial infection, unspecified } & Ayu6200 \\
\hline 225563 & Chlamydia cervicitis & K420900 \\
\hline 242170 & Chlamydial infection of genitourinary tract, unspecified & A78AX00 \\
\hline 242258 & {$[\mathrm{X}]$ Chlamydial infection of genitourinary tract, unspecified } & Ayu $4 \mathrm{~K} 00$ \\
\hline 251351 & Chlamydial infection of lower genitourinary tract & A78A000 \\
\hline 258276 & Chlamydia antigen by ELISA & $43 \cup 0.00$ \\
\hline 267536 & Chlamydia antigen test & $43 U . .00$ \\
\hline 278838 & Other viral and chlamydial diseases & A7 $\ldots 00$ \\
\hline 278847 & Other viral or chlamydial diseases & A78..00 \\
\hline 278852 & Chlamydial infection & A78A.00 \\
\hline 280340 & Chlamydial epididymitis & K241600 \\
\hline 285745 & Chlamydia antigen ELISA positive & $43 \cup 1.00$ \\
\hline 285746 & Chlamydia antigen ELISA negative & $43 \cup 2.00$ \\
\hline 287974 & Other specified viral and chlamydial diseases & A78y.00 \\
\hline 289351 & Chlamydial peritonitis & J550400 \\
\hline 297184 & Chlamydial infection of anus and rectum & A78A200 \\
\hline 297190 & Other specified viral or chlamydial diseases & A7y..00 \\
\hline 297288 & [X]Other diseases caused by chlamydiae & Ayu6.00 \\
\hline 302966 & INFECTION CHLAMYDIAL & 0399C \\
\hline 302967 & CHLAMYDIA TRACHOMATIS & 0399CT \\
\hline 307938 & Chlamydia trachomatis IgG level & $43 \mathrm{eJ} .00$ \\
\hline 308079 & Chlamydia trachomatis L2 antibody level & $43 \mathrm{eC} .00$ \\
\hline 308199 & Chlamydia group complement fixation test & $43 \mathrm{eF} .00$ \\
\hline 308461 & Chlamydia antibody level & $43 \mathrm{eE} .00$ \\
\hline 308950 & Chlamydia trachomatis polymerase chain reaction & $43 \mathrm{~h} 0.00$ \\
\hline 309472 & Chlamydia group antibody level & 43WM.00 \\
\hline 309613 & Chlamydia trachomatis IgM level & $43 \mathrm{ez} .00$ \\
\hline 309766 & Endocervical chlamydia swab & 4JK9.00 \\
\hline 309829 & Urethral chlamydia swab & 4JKA.00 \\
\hline 332003 & Chlamydia trachomatis IgA level & $43 n 9.00$ \\
\hline 342066 & Chlamydia trachomatis antigen test & $43 \cup 3.00$ \\
\hline 342214 & Chlamydia deoxyribonucleic acid detection & 43jK.00 \\
\hline 342310 & Chlamydia serology & 4JDM.00 \\
\hline 343726 & Urine screen for chlamydia & $68 \mathrm{~K} 7.00$ \\
\hline 343949 & Chlamydia PCR positive & $43 \cup 4.00$ \\
\hline 343968 & Chlamydia PCR negative & $43 \cup 5.00$ \\
\hline 344624 & Urine Chlamydia trachomatis test positive & $46 \mathrm{H} 6.00$ \\
\hline 344736 & Urine Chlamydia trachomatis test negative & $46 \mathrm{H} 7.00$ \\
\hline 345942 & Chlamydia screening declined & 813Т.00 \\
\hline 346998 & Chlamydia screening counselling & 677L.00 \\
\hline 347186 & Chlamydia trachomatis contact & 65PJ.00 \\
\hline 347227 & Low vaginal swab for chlamydia taken by patient & 4JKD.00 \\
\hline 347301 & Chlamydial infection of genital organs NEC & A78A500 \\
\hline 347315 & Chlamydia test offered & $90 q 0.00$ \\
\hline 347970 & Chlamydia test positive & $43 \cup 8.00$ \\
\hline 348085 & Chlamydia test negative & $43 \cup 6.00$ \\
\hline 348329 & Chlamydia test equivocal & $43 \cup 7.00$ \\
\hline
\end{tabular}


Appendix 1. Code lists:

\section{Tests for Neisseria gonorrhoea.}

\begin{tabular}{lll} 
GPRD Medical Code & Read/OXMIS Term & Read/ OXMIS Code \\
\hline 249090 & Gonorrhoea infect. titre test & $43 E 6.00$ \\
\hline 309228 & Neisseria gonorrhoeae polymerase chain reaction & $43 \mathrm{~h} 6.00$ \\
\hline 309635 & Neisseria gonorrhoeae nucleic acid detection & $43 \mathrm{JA} .00$ \\
\hline 340376 & Gonococcal swab & $4 \mathrm{JLA} .00$ \\
\hline 342356 & Gonococcal cervical swab & $4 \mathrm{JKB} .00$ \\
\hline 343558 & Gonococcal urethral swab & 4JKC.00 \\
\hline 348093 & Gonorrhoea test positive & 4JQA.00 \\
\hline 348381 & Gonorrhoea test negative & 4JQ8.00 \\
\hline
\end{tabular}




\begin{tabular}{|c|c|c|}
\hline GPRD Medical Code & Read/OXMIS Term & Read/ OXMIS Code \\
\hline 203712 & Infectious titres NOS & 43E..00 \\
\hline 203917 & Sample microscopy & 4115.00 \\
\hline 203918 & White cells seen on microscopy & 4115100 \\
\hline 203919 & RBCs seen on microscopy & 4115200 \\
\hline 203947 & High vaginal swab culture negative & 4JK2100 \\
\hline 203948 & HVS culture - Trichomonas vaginalis & 4JK2200 \\
\hline 205666 & Refer for microbiological test & $8 \mathrm{HP} 2.00$ \\
\hline 210464 & PENILE SWAB CULTURE NEGATIVE & L 167DN \\
\hline 210515 & HVS TRICHOMONAS VAGINALIS & L1670FT \\
\hline 212942 & Sample culture & $4 \mathrm{~J} 17.00$ \\
\hline 212962 & Semen sent for $\mathrm{C} / \mathrm{S}$ & 4JL8.00 \\
\hline 219515 & SWAB CERVICAL ABNORMAL & L 167FC \\
\hline 219570 & HVS LACTOBACILLI & L1670FL \\
\hline 221698 & Direct microscopy & 31B1.00 \\
\hline 222017 & Sample: no organism isolated & $4 J 11.00$ \\
\hline 222018 & Sample: organism isolated & $4 \mathrm{~J} 12.00$ \\
\hline 222020 & Sample: bacteriology - general & $4 \mathrm{~J} 2 . .00$ \\
\hline 222022 & Sensitivity-bacteriology & $4 \mathrm{~J} 2 . .13$ \\
\hline 222038 & Microbiology NOS & $4 \mathrm{JJZ} . .00$ \\
\hline 228578 & MICROBIOLOGY REPORT ABNORMAL & L 2MA \\
\hline 228611 & HVS CULTURE NEGATIVE & L 167FN \\
\hline 228613 & SWAB CULTURE BACTERIAL GROWTH & L 167XE \\
\hline 230862 & Blood sent - infectious titres & 43E1.00 \\
\hline 231003 & Parasite in urine & $46 \mathrm{H} . .15$ \\
\hline 231090 & Microbiology & 4J...00 \\
\hline 231091 & Sample - microbiological exam & $4 \mathrm{~J} 1 . .00$ \\
\hline 231094 & Sample: dir.micr.:no organism & $4 J 71.00$ \\
\hline 231095 & Bacteria on microscopy & 4J72.11 \\
\hline 231108 & Urethral swab culture positive & 4JK1000 \\
\hline 231109 & High vaginal swab: white cells seen & 4JK2500 \\
\hline 231110 & Vaginal swab culture negative & 4JK6.00 \\
\hline 237538 & MICROBIOLOGY REPORT & L 2MR \\
\hline 237571 & VAGINAL SWAB CULTURE POSITIVE & L 167FZ \\
\hline 237574 & SWAB CULTURE FUNGAL GROWTH & L 167XC \\
\hline 237587 & VIRAL TITRES & L 189D \\
\hline 237617 & HVS GARDNERELLA VAGINALIS & L1670FG \\
\hline 237618 & HVS YEAST & L1670FY \\
\hline 240066 & Sample: direct micr. organism & 4J7...00 \\
\hline 240075 & High vaginal swab culture positive & 4JK2000 \\
\hline 240076 & HVS culture - Gardnerella vaginalis & 4JK2300 \\
\hline 240077 & Low vaginal swab taken & 4JK3.00 \\
\hline 240078 & Misc. sample for organism & 4JL..00 \\
\hline 246733 & SWAB CERVICAL & L 167FA \\
\hline 246735 & URETHRAL SWAB CULTURE NEGATIVE & L 167IN \\
\hline 249028 & Swab sent to Lab & 4147.00 \\
\hline 249310 & Culture - general & 4J...11 \\
\hline 249324 & Cervical swab culture positive & 4JK5000 \\
\hline 258486 & Sample: microbiology NOS & 4J1Z.00 \\
\hline
\end{tabular}


Appendix 1. Code lists:

D. Other microbial tests continued.

\begin{tabular}{|c|c|c|}
\hline 258503 & Urethral swab culture negative & 4JK1100 \\
\hline 258504 & Vaginal swab culture positive & 4JK7.00 \\
\hline 258505 & Penile swab culture positive & 4JK8000 \\
\hline 258506 & Penile swab culture negative & 4JK8100 \\
\hline 265145 & PENILE SWAB & L 167D \\
\hline 265146 & PENILE SWAB CULTURE POSITIVE & L 167DP \\
\hline 265197 & HVS WBC & L1670FW \\
\hline 267662 & Urine microscopy: orgs/FBs & $46 \mathrm{H} . .00$ \\
\hline 267735 & Sensitivity-microbiol. & 4J...12 \\
\hline 267736 & Sample: organism sensitivity & $4 J 15.00$ \\
\hline 267739 & O/E: stained micr.: organism & $4 \mathrm{~J} 8 . .00$ \\
\hline 267754 & Vaginal swab taken & $4 \mathrm{JK} . .11$ \\
\hline 267755 & Vulval swab taken & 4JK4.00 \\
\hline 267756 & Penile swab taken & 4JK8.00 \\
\hline 267757 & GUT swab NOS & 4JKZ.00 \\
\hline 274368 & HVS EPITHELIAL CELLS & L1670FE \\
\hline 276782 & Culture - bacteriology & $4 \mathrm{~J} 2 . .12$ \\
\hline 276783 & Sample sent for culture/sensit & 4J22.00 \\
\hline 276800 & GUT sample taken for organism & 4JK..00 \\
\hline 276801 & High vaginal swab taken & 4JK2.00 \\
\hline 276802 & Cervical swab taken & 4JK5.00 \\
\hline 283373 & HVS & L 167F \\
\hline 283374 & HVS CULTURE POSITIVE & L 167FP \\
\hline 283375 & VAGINAL SWAB CULTURE NEGATIVE & L 167FY \\
\hline 285938 & Microscopy, culture and sensitivities & 4116.00 \\
\hline 285943 & Sample: bacteria cultured & 4J23.00 \\
\hline 285955 & Urethral swab taken & 4JK1.00 \\
\hline 285958 & Microbiology test & 4JQ..00 \\
\hline 292462 & MICROBIOLOGY REPORT NORMAL & $\mathrm{L} 2 \mathrm{MN}$ \\
\hline 292509 & SWAB CERVICAL NORMAL & L 167FB \\
\hline 292511 & URETHRAL SWAB CULTURE POSITIVE & L 167IP \\
\hline 292515 & SWAB CULTURE NO GROWTH & L 167XB \\
\hline 295145 & High vaginal swab: fungal organism isolated & 4JK2400 \\
\hline 295146 & Cervical swab culture negative & 4JK5100 \\
\hline 297019 & Microbiology report received & 9ND3.00 \\
\hline 301878 & VAGINAL SWAB & L 167FX \\
\hline 301879 & URETHRAL SWAB & L $167 \mid$ \\
\hline 301882 & SWAB CULTURE YEAST GROWTH & L 167XD \\
\hline 308931 & Bacterial antibody level & $43 e . .00$ \\
\hline 309727 & Microscopy & 4JS..00 \\
\hline 331709 & Gram stain microscopy & 4JS0.00 \\
\hline 332043 & Anaerobic culture & 4J18.00 \\
\hline 339918 & Concentrate microscopy & 4JS2.00 \\
\hline 340342 & Genital microscopy, culture and sensitivities & $411 \mathrm{C} .00$ \\
\hline 340745 & Fluid microscopy, culture and sensitivities & 4I1D.00 \\
\hline 343815 & Semen microscopy & 49L..00 \\
\hline 343816 & Aerobic culture & $4 \mathrm{~J} 19.00$ \\
\hline 344353 & Additional urine tests & $46 h . .00$ \\
\hline 345784 & Culture for fungi & $4 \mathrm{~J} 45.00$ \\
\hline
\end{tabular}




\begin{tabular}{|c|c|c|}
\hline 350883 & Low vaginal swab taken by patient & 4JKE.00 \\
\hline 350959 & Self taken low vaginal swab & 4JKE.11 \\
\hline 203821 & Urine exam. - general & $461 . .00$ \\
\hline 203822 & Urine dipstick test & 4618.00 \\
\hline 203825 & Urine protein test $=+$ & 4674.00 \\
\hline 203826 & Urine protein test $=++$ & 4675.00 \\
\hline 203827 & Urine ketone test $=++++$ & 4687 \\
\hline 203831 & Urine sent for microscopy & 46D1.00 \\
\hline 203832 & Urine microscopy: no casts & 46E1.00 \\
\hline 203840 & Urine culture - no growth & 46U1.00 \\
\hline 203841 & Urine culture - E. coli & 46U3.00 \\
\hline 203842 & Urine culture - Str. faecalis & $46 \cup 5.00$ \\
\hline 203843 & Urine culture - Staph. albus & $46 \cup 6.00$ \\
\hline 203844 & Urine culture - Bacteria OS & $46 \cup 8.00$ \\
\hline 210442 & URINE INVESTIGATIONS & L 131AA \\
\hline 210443 & URINE CASTS PRESENT & L 132CP \\
\hline 210520 & ABNORMAL URINE TEST NOT YET DIAGNOSED & L2590AN \\
\hline 210544 & URINE NEGATIVE & L7891N \\
\hline 211701 & STERILE PYURIA & $7891 \mathrm{D}$ \\
\hline 212820 & Urine examination & $46 \ldots 00$ \\
\hline 212821 & MSU sent to lab. & 4615.00 \\
\hline 212822 & Urine inspection & $462 . .00$ \\
\hline 212823 & Urine: cloudy & 4627 \\
\hline 212827 & Urine protein test $=++++$ & 4677 \\
\hline 212830 & Urine: trace non-haemol. blood & 4693.00 \\
\hline 212840 & Urine Microscopy: white cells & 46G8.00 \\
\hline 212959 & Urine for culture & 4JJ..13 \\
\hline 212960 & Early morning urine & 4JJ..14 \\
\hline 212961 & Urine sample for organism NOS & 4JJZ.00 \\
\hline 219490 & MSU NORMAL & L 133MN \\
\hline 219573 & URINE ALBUMIN +++ & L2400CC \\
\hline 219576 & CASTS IN URINE POSITIVE & L2591PV \\
\hline 221916 & $\mathrm{MSU}=$ no abnormality & 4616.00 \\
\hline 221921 & Urine blood test & $469 . .00$ \\
\hline 221922 & Urine bacteria test NOS & 46BZ.00 \\
\hline 221923 & Urine microscopy: no crystals & $46 \mathrm{~F} 1.00$ \\
\hline 221924 & Sterile pyuria & 46G4.12 \\
\hline 221925 & Urine micr.: bacteria present & $46 \mathrm{H} 4.00$ \\
\hline 221955 & Urine culture - Escherich. coli & 46U3.11 \\
\hline 222034 & MSU sent for bacteriology & 4JJ2.00 \\
\hline 228591 & URINE CULTURE POSITIVE GROWTH & L 133P \\
\hline 228673 & URINE ALBUMIN + & L2400AA \\
\hline 230985 & Urinalysis requested & 4612.00 \\
\hline 230986 & Urine $=$ normal on inspection & 4621.00 \\
\hline 230987 & Urine inspection NOS & $462 Z .00$ \\
\hline 230993 & Urine protein test & $467 . .00$ \\
\hline 230994 & Urine protein test negative & 4672.00 \\
\hline 230995 & Urine dipstick for protein & 4679.00 \\
\hline 230996 & Urine: trace haemolysed blood & 4694.00 \\
\hline
\end{tabular}


Appendix 1. Code lists:

D. Other microbial tests continued.

\begin{tabular}{|c|c|c|}
\hline 230997 & Urine microscopy: no cells & 46G1.00 \\
\hline 230998 & RBCs - red blood cells in urine & $46 G 2.11$ \\
\hline 230999 & Urine micr.: leucocytes present & $46 \mathrm{G} 4.00$ \\
\hline 231000 & Leucocytes in urine & $46 \mathrm{G} 4.11$ \\
\hline 231001 & Urine micr.: leucs $-\%$ polys & $46 G 5.00$ \\
\hline 231002 & Pus cells in urine & $46 G 7.11$ \\
\hline 231003 & Parasite in urine & $46 \mathrm{H} . .15$ \\
\hline 231031 & Urine culture - mixed growth & $46 U 2.00$ \\
\hline 237549 & URINE CULTURE & L 133 \\
\hline 237622 & URINE ALBUMIN ++ & L2400BB \\
\hline 237649 & URINE TEST & L7890T \\
\hline 239977 & Urine protein test $=$ trace & 4673.00 \\
\hline 239980 & Urine microscopy - general NOS & 46DZ.00 \\
\hline 239981 & Urine microscopy - casts & 46E..00 \\
\hline 239982 & Urine microscopy: epith. casts & 46E2.00 \\
\hline 239986 & FB in urine - microscopy & $46 \mathrm{H} . .12$ \\
\hline 239987 & Urine microscopy: no orgs/FBs & $46 \mathrm{H} 1.00$ \\
\hline 240073 & Mid-stream urine sample & 4JJ..12 \\
\hline 240074 & Urine sent for culture & 4JJ3.00 \\
\hline 246820 & MSU & L7891MS \\
\hline 249215 & Urine exam. - general NOS & $461 Z .00$ \\
\hline 249223 & Urine dipstick for blood & 4698.00 \\
\hline 249224 & Urine bacteriuria test & 46B..00 \\
\hline 249225 & Urine bacteria test: positive & 46B3.00 \\
\hline 249226 & Urine microscopy - general & 46D..00 \\
\hline 249227 & Urine micr.: leucs - \% lymphs & $46 G 6.00$ \\
\hline 249228 & Urine microscopy: red cells & 46G9.00 \\
\hline 249229 & Bacteria in urine $\mathrm{O} / \mathrm{E}$ & $46 \mathrm{H} . .11$ \\
\hline 249242 & Urine test NOS & $46 Z . .00$ \\
\hline 249322 & Urine sample for organism & 4JJ..00 \\
\hline 255953 & URINE WBC'S ABSENT & L 132WA \\
\hline 255954 & URINE WBC'S PRESENT & L 132WP \\
\hline 258374 & MSU = equivocal & 461A.00 \\
\hline 258375 & Urine: red - blood & 4625.00 \\
\hline 258376 & Urine: looks clear & 4626 \\
\hline 258381 & Proteinuria & 4678.00 \\
\hline 258384 & Urine blood test $=++$ & 4696.00 \\
\hline 258385 & Urine blood test $=+++$ & 4697.00 \\
\hline 258386 & Urine bacteria test: negative & 46B2.00 \\
\hline 258387 & Urine microscopy: casts NOS & 46EZ.00 \\
\hline 258390 & Urine microscopy: cells & 46G..00 \\
\hline 258391 & Urine microscopy: RBCs present & 46G2.00 \\
\hline 258392 & Urine microscopy: pus cells & $46 \mathrm{G} 7.00$ \\
\hline 258398 & Urine protein & $46 N . .00$ \\
\hline 258399 & Urine protein abnormal & $46 \mathrm{~N} 2.00$ \\
\hline 258414 & Urine culture & 46U..00 \\
\hline 258502 & MSU sent for $\mathrm{C} / \mathrm{S}$ & 4JJ1.00 \\
\hline 265127 & URINE CULTURE NO GROWTH & L 133N \\
\hline 265202 & PROTEINURIA & L2020PV \\
\hline
\end{tabular}


Appendix 1. Code lists:

D. Other microbial tests continued.

\begin{tabular}{|c|c|c|}
\hline 267459 & Urine sample sent to Lab & 4146.00 \\
\hline 267646 & Urine tests & $46 \ldots 11$ \\
\hline 267647 & MSU - general & $461 . .11$ \\
\hline 267648 & $\mathrm{MSU}=$ no growth & 4619.00 \\
\hline 267653 & Blood in urine test & $469 . .11$ \\
\hline 267655 & Urine blood test $=+$ & 4695.00 \\
\hline 267656 & Urine blood test NOS & 469Z.00 \\
\hline 267658 & Urine microscopy = abnormality & 46D3.00 \\
\hline 267659 & Urine microscopy: crystals & $46 F . .00$ \\
\hline 267660 & Urine micr.: uric acid crystals & 46F3.00 \\
\hline 267661 & Urine microscopy: no white cells & $46 \mathrm{G} 1100$ \\
\hline 267662 & Urine microscopy: orgs/FBs & $46 \mathrm{H} . .00$ \\
\hline 274306 & URINE EPITHELIAL CELLS PRESENT & L 132EP \\
\hline 274307 & MSU ABNORMAL & L 133MA \\
\hline 276691 & Urinalysis - general & $461 . .12$ \\
\hline 276695 & Urine blood test $=$ negative & 4692.00 \\
\hline 276697 & Urine microscopy:hyaline casts & 46E3.00 \\
\hline 276799 & Catheter urine $\rightarrow$ culture. & 4JJ4.00 \\
\hline 285852 & Urinalysis $=$ no abnormality & 4613.00 \\
\hline 285853 & Urinalysis $=$ abnormal & 4614.00 \\
\hline 285854 & $\mathrm{MSU}=$ abnormal & 4617.00 \\
\hline 285855 & Urine: pale & 4624 \\
\hline 285858 & Urine protein test $=+++$ & 4676.00 \\
\hline 285859 & Urine protein test NOS & 467Z.00 \\
\hline 285866 & Urine micr.: orgs/FBs NOS & $46 \mathrm{HZ} .00$ \\
\hline 292486 & URINE INVESTIGATIONS ABNORMAL & L 131AC \\
\hline 295030 & Urine microscopy: no epithelial cells & 46G1000 \\
\hline 295031 & Urine micr:: epithelial cells & 46G3.00 \\
\hline 301855 & URINE INVESTIGATIONS NORMAL & $\mathrm{L} 131 \mathrm{AB}$ \\
\hline 302605 & Urine microalbumin positive & $46 w 0.00$ \\
\hline 333181 & Urine leucocyte test & $46 f . .00$ \\
\hline 333245 & Urine leucocyte test $=+$ & $46 f 2.00$ \\
\hline 333246 & Urine leucocyte test $=++$ & $46 f 3.00$ \\
\hline 333247 & Urine leucocyte test $=+++$ & $46 f 4.00$ \\
\hline 335402 & Urine microscopy & $46 Z 1.00$ \\
\hline 339791 & Urine leucocyte test $=$ negative & $46 f 1.00$ \\
\hline 340095 & Urine microscopy: yeasts & $46 \mathrm{H} 5.00$ \\
\hline
\end{tabular}




\section{Appendix 2. Results of sensitivity analyses.}

28-day management window (1575 orchitis-only cases excluded)

$<35$ years, $\% \quad \geq 35$ years, $\%$

Management

Managed in practice

No evidence of management

58.2

Evidence of care elsewhere

56.0

19.0

16.9

Drug prescribed

Any recommended drug

25.0

24.9

Ciprofloxacin

$56.6 \quad 55.7$

Doxycycline

Test carried out

Chlamydia trachomatis test

Microbial test

Urine test

4.6

11.8

42-day management window

\section{Management}

Managed in practice

$52.5 \quad 55.3$

No evidence of management

17.8

55.3

Evidence of care elsewhere

29.7

Drug prescribed

Any recommended drug

55.4

55.4

Ciprofloxacin

37.0

Doxycycline

34.4

17.5

Test carried out

Chlamydia trachomatis test

20.5

Microbial test

1.5

Urine test

60-day management window

Management

\section{Managed in practice}

23.8

No evidence of management

Evidence of care elsewhere

Drug prescribed

Any recommended drug

Ciprofloxacin

Doxycycline

Test carried out

Chlamydia trachomatis test $\quad 4.5 \quad 13.6$

Microbial test

Urine test

90-day management window

\section{Management}

Managed in practice

No evidence of management

Evidence of care elsewhere

Drug prescribed

Any recommended drug

38.2

38.9

Ciprofloxacin

Doxycycline

Test carried out

Chlamydia trachomatis test

Microbial test 